\title{
Analysis of Rainfall and Temperature Trends in Bahati Sub- County, Kenya
}

\author{
Jackson K. Koimbori ${ }^{1,4, *}$, Chris A. Shisanya ${ }^{2}$, Shadrack K. Murimi ${ }^{3}$ \& Rickard Petterson ${ }^{4}$ \\ ${ }^{1}$ Department of Geography, Kenyatta University \\ Nairobi, Kenya \\ ${ }^{2}$ Department of Geography, Kenyatta University \\ Nairobi, kenya \\ ${ }^{3}$ Department of Geography, Kenyatta University \\ Nairobi, kenya \\ ${ }^{4}$ Department of Earth Sciences, Uppsala Universitet \\ Uppsala, Sweden \\ *Corresponding author's email: Jackson_kinyanjui [AT] yahoo.co.uk
}

\begin{abstract}
This study analyzed the climate variability trends in Bahati Sub-County, Kenya for the period 1985 to 2015.The climate parameters used included rainfall onset, rainfall cessations, seasonal rain, annual rainfall, annual mean temperature, maximum and minimum temperature. Data on rainfall and temperature was collected from Nakuru Meteorological Station. The strength and direction of the relationship between rainfall and temperature was determined using SPSS software version 23 (correlation analysis) and Microsoft Office Excel 2010 to generate frequency tables, pie charts, graphs and moving averages. The findings revealed that there is a significant, negative and strong relationship between annual rainfall trend and maximum temperature $(r=-0.716, p=0.000)$. However, the study findings also revealed that the relationship between annual rainfall and minimum temperature had an insignificant, weak and negative relationship $(r=0.151, p=0.418)$.
\end{abstract}

Keywords---- climate variability, rainfall, temperature

\section{INTRODUCTION}

The global surface temperatures in the last three decades and past century have warmed up by $0.6^{\circ} \mathrm{C}$ and $0.8^{\circ} \mathrm{C}$ respectively [4]. In 1992 the International Political Response to Climate Change (IPRCC) began with the ratification of the United Nation Framework Convention on Climate Change (UNFCCC). Stabilizing the greenhouse gases concentration in the atmosphere at a threshold that would avert severe anthropogenic interference with the present climatic systems in our world was the main purpose of the convention. This led to the signing of the Kyoto protocol of 1997 committing countries towards taking up climate action. According to the National Climate Change Action Plan (NCCAP), 2013 report, climate change can be monitored through measurement of the climatic parameters like wind, pressure, temperature and rainfall among others [3]. Climate change research studies have predicted an increase of precipitation and temperature throughout the year with an annual average of $4.2 \mathrm{~mm}$ and $+2.8^{\circ} \mathrm{C}$ per month respectively over tropical Africa. In Kenya data from National Climate Change Response Strategy (NCCRS) in 2010 indicated that the country's day and night temperatures have increased by as much as $2.1^{\circ} \mathrm{C}$ and $2.9^{\circ} \mathrm{C}$ respectively in western part of Kenya in the last twenty years. Meanwhile in central Kenya, which includes Nairobi the night and day temperatures have risen by $2.0^{\circ} \mathrm{C}$ and $0.7^{\circ} \mathrm{C}$ respectively. In the southern-eastern region, which includes Kenya's food basket, the rift valley temperatures have risen by $1^{\circ} \mathrm{C}$. In Nairobi both maximum and minimum temperatures have shown an increasing trend for the period 1966 to 1999 [9]. Climate change and variability in Kenya has led the Government of Kenya to commit approximately Kenya Shillings (KES) 37 billion, while development partners have committed KES 194 billion between 2005 and 2015 to programs they have earmarked as having a major impact on climate change components [3]. The residents of Bahati Sub-County, Kenya have been experiencing increasing temperatures and variations in rainfall amounts. This research study therefore sought to analyse the rainfall and temperature trends in Bahati Sub-County, Kenya for the period 1985 to 2015 with the aim of providing the locals with a better understanding of the rainfall and temperature trends. 


\section{METHODOLOGY}

\subsection{Study Area}

The study was carried out in Bahati Sub-County which is located within Nakuru County, Kenya (Fig. 1). It is made up of 5 wards of which 4 wards will be studied; Dundori ward, Kabatini ward, Kiamaina ward and Bahati ward, since Lanet/Umoja is not an agricultural area. The greater Nakuru County is in Rift valley province and occupies an area of $7,242.3 \mathrm{~km}^{2}$. It is located between longitudes $35^{\circ} 28^{\prime}$ and $35^{\circ}$ east and Latitude $0^{\circ} 13^{\prime}$ and $10^{\circ} 10^{\prime}$ South at an altitude of about 1912 meters above sea level. Bahati Sub-County has a population of 141,352 covering an area of $375.40 \mathrm{~km}^{2}$ [7]. Nakuru County has predictable weather patterns with temperatures ranging between $10^{\circ} \mathrm{C}$ during the cold months (July and August) and $20^{\circ} \mathrm{C}$ during the hot months (January to March). Bahati Sub-County receives between 700mm and $1200 \mathrm{~mm}$ of rainfall annually, with average annual rainfall being an approximated $960 \mathrm{~mm}$. Nakuru County which covers Bahati Sub-County has two rainy seasons; March, April, May (long rains) and October, November, December (short rains) [3]. The soils are complex due to influence by variations in relief, climate and underlying rock types. The major soils fall into three categories; Latosolic soils, Planosolic soils and Alluvial soils [3].

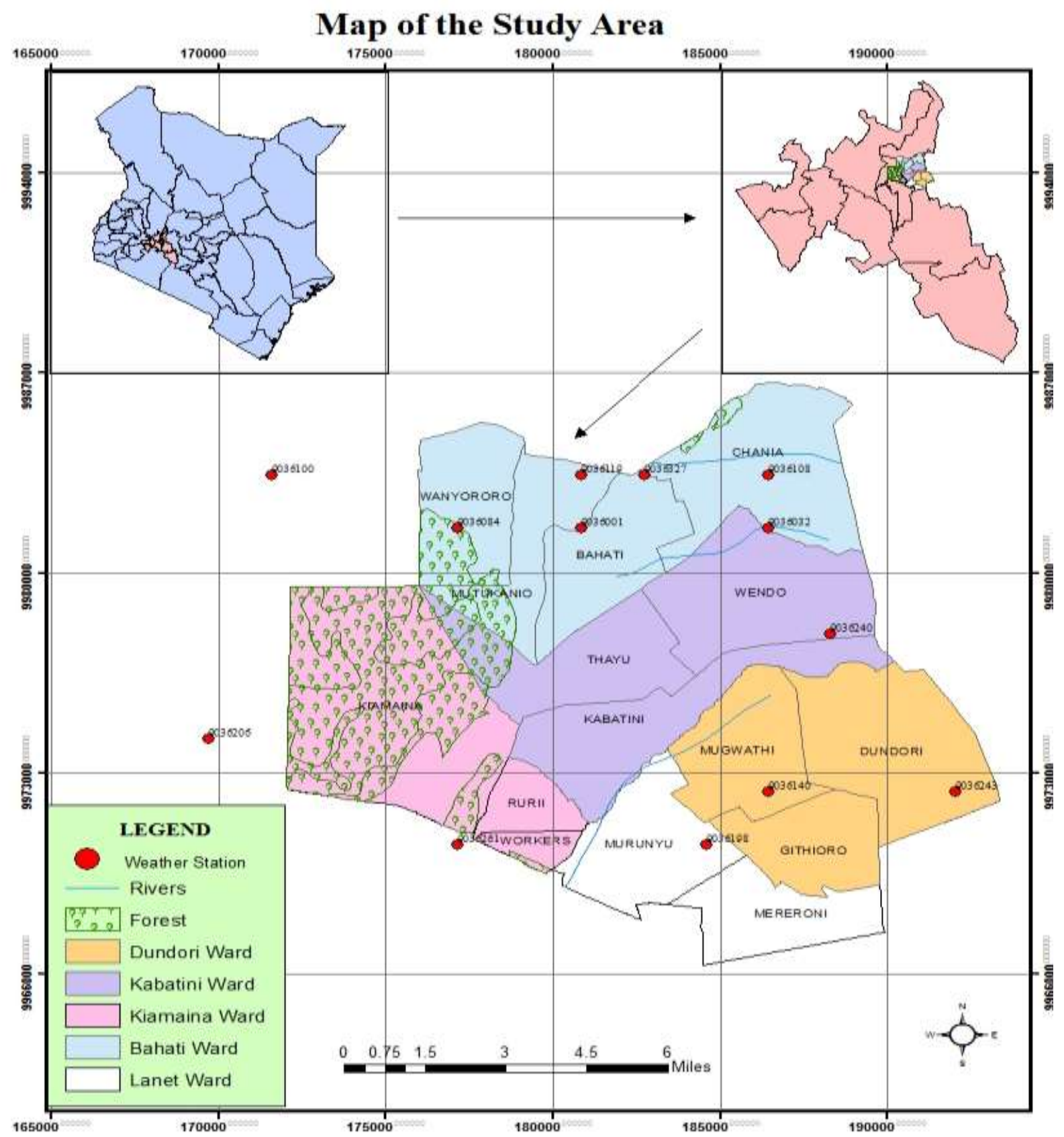

Figure 1. A Map of Bahati sub-county showing study site. 


\subsection{Climate Data}

A span of the most recent thirty year records from 1985 to 2015 was collected from Nakuru Meteorological Station. The climate data was a representative of the most recent average climate in the study region and the 30 years' span was sufficient duration to encompass a range of significant weather anomalies depicting monthly rainfall and temperature trends in Bahati Sub-County, Nakuru County. The rainfall and temperature characteristics for Bahati Sub-County were recorded in a summary check sheet and this included rainfall onset, rainfall cessations, seasonal rain, annual rainfall, seasonal maximum and minimum temperature.

\subsection{Data Analysis}

The collected data was analysed using descriptive and inferential statistics. Descriptive statistics included measures of central tendency and measures of dispersion. The mean rainfall and temperature for the period 1985 to 2015 was determined from Nakuru Meteorological Station. Consequently, statistics on the inter-annual standard deviation and variance of rainfall and temperature for the same period were calculated.

\section{RESULTS}

\subsection{Rainfall Trends}

\subsubsection{Annual Rainfall Trend}

The results in Fig. 2, shows that the annual rainfall amount has reduced between 1985 and 2015 in Bahati Sub-County. High amounts of rainfall are noticed in the years $1988(1244 \mathrm{~mm}), 1992(980 \mathrm{~mm}), 1997(1094 \mathrm{~mm}), 2001(1130 \mathrm{~mm}), 2002$ $(1084 \mathrm{~mm}), 2003(1138 \mathrm{~mm}), 2007(1217 \mathrm{~mm}), 2010(1436 \mathrm{~mm})$ and $2013(1185 \mathrm{~mm})$, while low amounts of rainfall are noticed in the years $1987(697 \mathrm{~mm}), 1993(704 \mathrm{~mm}), 2000(610 \mathrm{~mm})$ and $2009(705 \mathrm{~mm})$. The rainfall variability shown in the results above supports the argument that the ASALs in Kenya have been impacted negatively by high rainfall variability $[10,11]$.

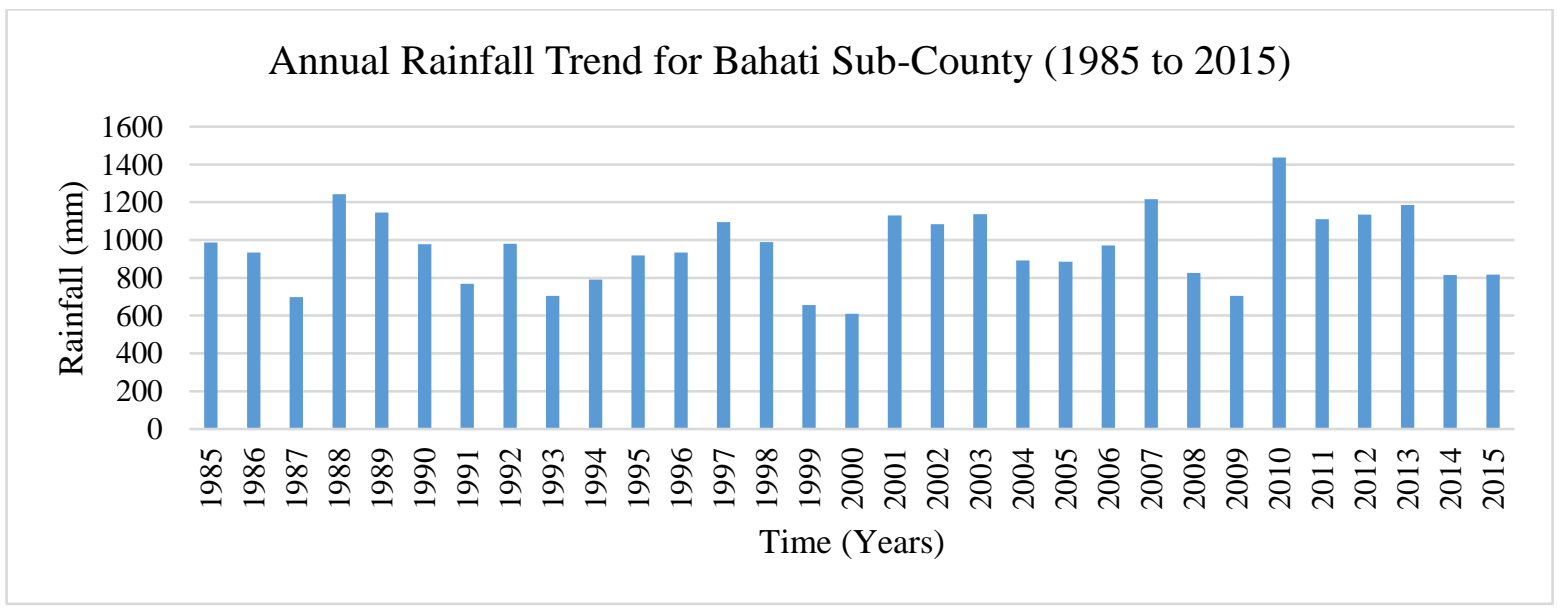

Figure 2: Annual Rainfall Trend for Bahati Sub-County

\subsubsection{Seasonal Rainfall Trends}

The extreme events were observed both during the long and short rainfall season. During the long rainfall season high amounts of rainfall were recorded during the years $1985(505 \mathrm{~mm}), 1988(575 \mathrm{~mm}), 1990(487 \mathrm{~mm}), 2003(464 \mathrm{~mm}), 2010$ $(585 \mathrm{~mm})$, and $2012(453 \mathrm{~mm})$, while low amounts of rainfall were recorded in $1993(125 \mathrm{~mm}), 1996(199 \mathrm{~mm}), 2000$ $(69 \mathrm{~mm})$, and $2008(179 \mathrm{~mm})$ (Fig. 3). Further, during the short rainfall season high amounts of rainfall were recorded during the years $1989(347 \mathrm{~mm}), 1997(464 \mathrm{~mm}), 2002(384 \mathrm{~mm}), 2006(352 \mathrm{~mm}), 2008(311 \mathrm{~mm})$ and $2015(315 \mathrm{~mm})$, while low amounts of rainfall were recorded in $1985(106 \mathrm{~mm}), 1993(126 \mathrm{~mm})$ and $2005(112 \mathrm{~mm})$ (Fig. 3). According to a 2007 report by Intergovernmental Panel on Climate Change (IPCC), changes in rainfall pattern in East Africa is as a result of the El Niño phenomena [6] and this supports our findings on the seasonal rainfall pattern fluctuations in Bahati Sub-County. 


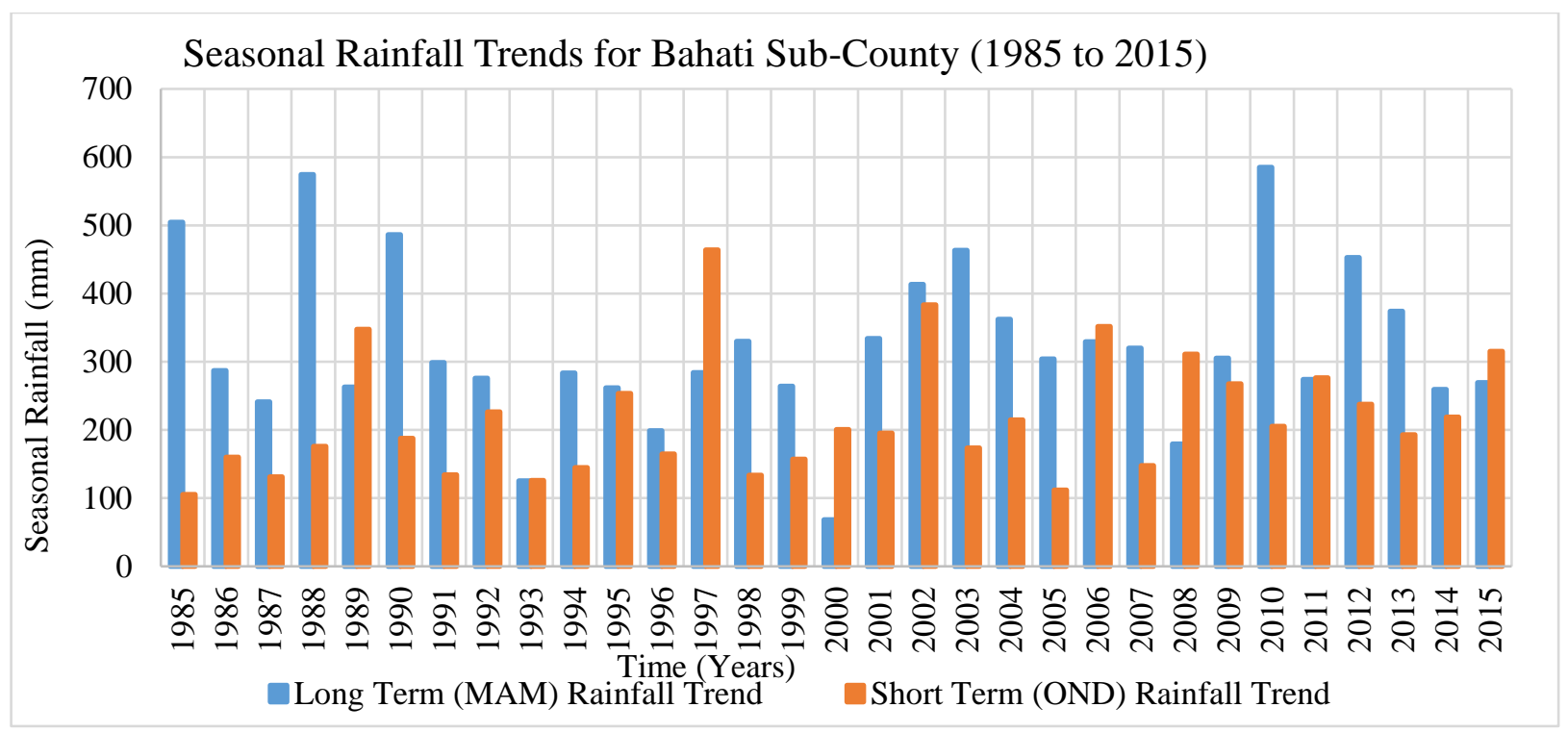

Figure 3: Seasonal Rainfall Trend for Bahati Sub-County

\subsection{Rainfall Variability}

The annual rainfall variability characteristics for Bahati Sub-County (1985 to 2015) were computed when annual rainfall anomalies were presented in the graph as shown in Fig. 4. Annual rainfall variability ranges from $-350.40 \mathrm{~mm}$ in 2000 to $+475.80 \mathrm{~mm}$ in 2010 as shown in Fig. 4. The highest rainfall anomalies were recorded in years $1987(-263.2 \mathrm{~mm}), 1988$ $(+283.2 \mathrm{~mm}), 1993(-256.5 \mathrm{~mm}), 1999(-303.6 \mathrm{~mm}), 2000(-350.4 \mathrm{~mm}), 2007$ (+256.9mm), $2009(-255.1 \mathrm{~mm}), 2010$ $(+475.8 \mathrm{~mm})$ and $2013(+224.4 \mathrm{~mm})$.

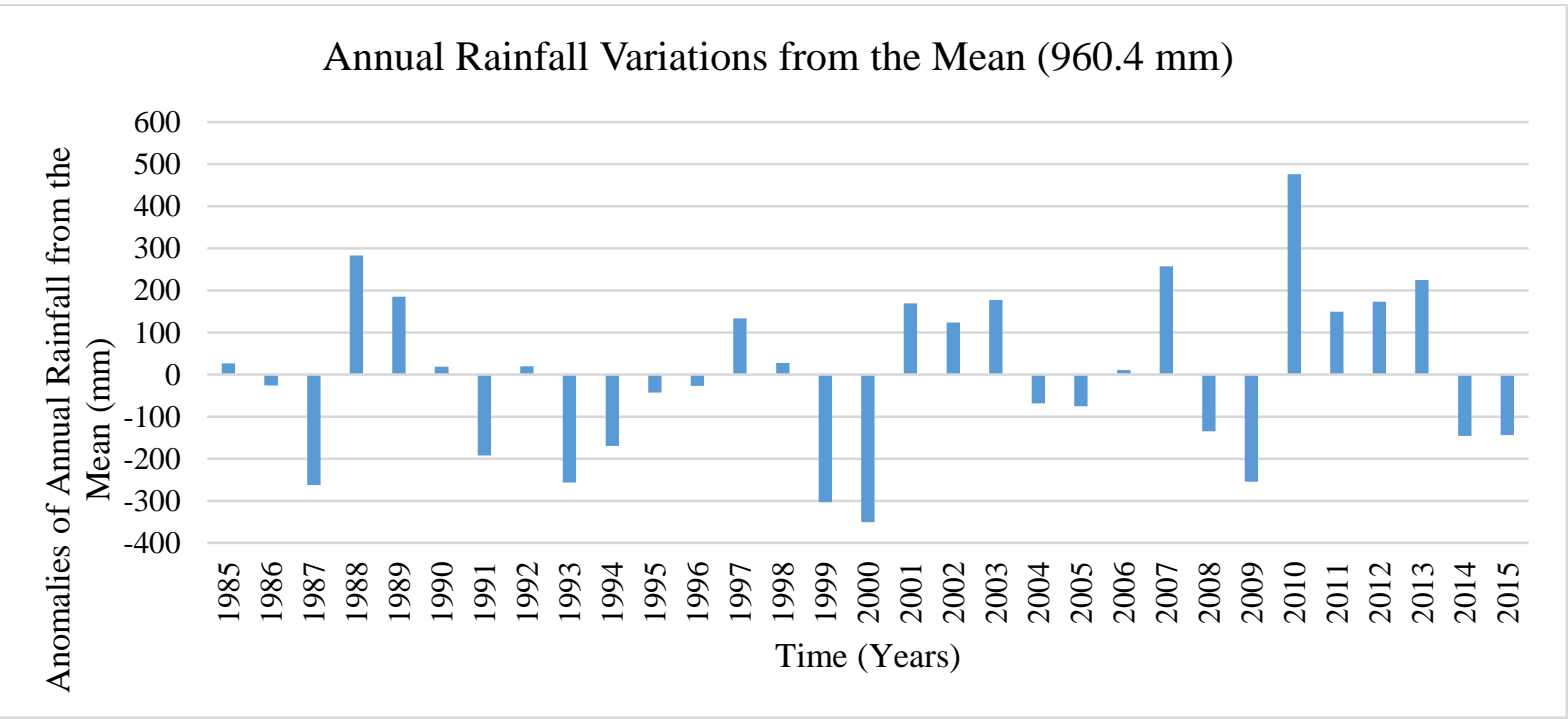

Figure 4: Annual Rainfall Variations for Bahati Sub-County

\subsubsection{Seasonal Rainfall Variations}

The variability in seasonal rainfall (long and short), and occurrence of extreme events have effects on maize yield in the area exposing small scale farmers to climate change vulnerability. This collaborates with various studies that have shown that changes in seasonal rainfall patterns have a negative effect on rain fed agriculture [2,5]. Rainfall variability is significant in the long rain season trend and ranges from $(-253.17 \mathrm{~mm})$ in 2000 to $(+263.53 \mathrm{~mm})$ in 2010 as shown in Fig. 5. Rainfall variability is also significant in the short rain season trend and ranges from $(-111.08 \mathrm{~mm})$ in 1985 to $(+247.31 \mathrm{~mm})$ in 1997 as shown in Fig. 5. During the long rains (MAM) the highest rainfall variations were recorded in 1985 (+182.8mm), 1988 (+253.0mm), $1993(-196.6 \mathrm{~mm}), 2000(-253.2 \mathrm{~mm})$ and $2010(+263.5 \mathrm{~mm})$, while during the short rains (OND) the highest rainfall variations were recorded in 1985(-111.08mm), $1989(+130.7 \mathrm{~mm}), 1997(+247.3 \mathrm{~mm})$, $2002(+167.0 \mathrm{~mm}), 2005(-104.6 \mathrm{~mm})$ and $2006(+134.8 \mathrm{~mm})$. 


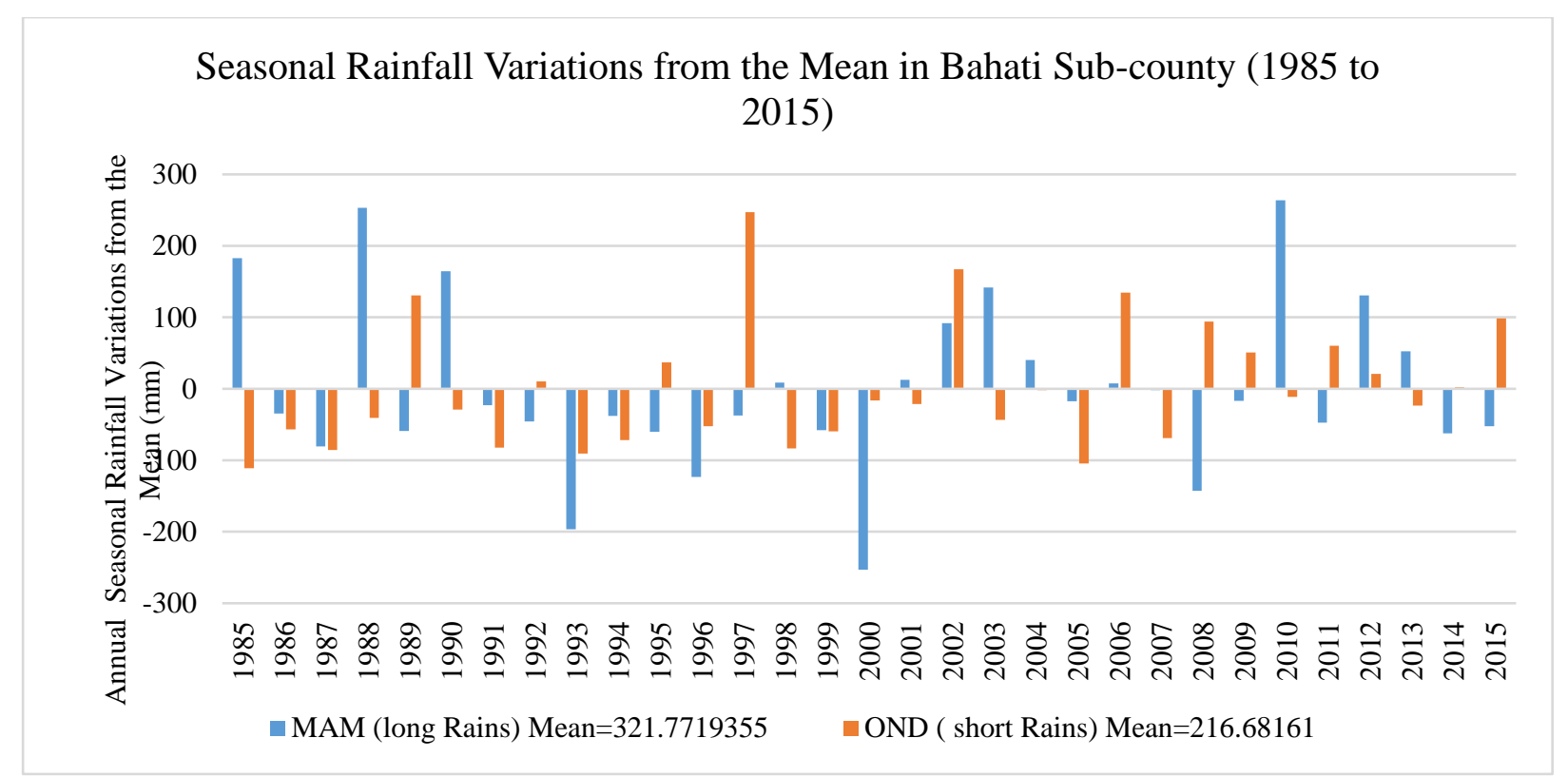

Figure 5: Seasonal Rainfall Variations for Bahati Sub-County

\subsection{Seasonal Rainfall Onset and Cessation}

The results in Table 1 shows that onset month for Long rain season has varied, alternating between March and April. 18 times representing 58.1\% the onset was in March and 13 times representing 41.9\% the onset was in April. Cessation month has also varied alternating between June, July and August. When farmers are informed on the onset date they plan on when to prepare their land and acquire the necessary inputs. This finding supports the earlier findings by [1] that the onset time for long term rainfall is normally used by farmers to determine the time they clear and prepare the land for planting. The peak months' range from March, April and May. The results in Table 1 shows that the onset month for the short rain season has varied, alternating between October, November and December. 23 times representing $74.2 \%$ the onset was in October, 7 times representing 22.6\% the onset was in November and 1 time representing 3.2\% the onset was in December. Cessation month has also varied alternating between November, December and January. The peak months' range from October, November and December. The results found that seasonal rainfall change is a challenge to Bahati Sub-County farmers and they need to be updated at all times to enable them plant on time. 
Table 1: Summary of Seasonal Rainfall Characteristics for Bahati Sub-County

\begin{tabular}{|c|c|c|c|c|c|c|}
\hline Year & $\begin{array}{l}\text { Peak Month } \\
\text { of Rainfall } \\
\text { During the } \\
\text { Long Rain } \\
\text { Season }\end{array}$ & $\begin{array}{l}\text { Onset } \\
\text { Month of } \\
\text { Rainfall } \\
\text { During the } \\
\text { Long Rain } \\
\text { Season }\end{array}$ & $\begin{array}{l}\text { Cessation } \\
\text { Month of } \\
\text { Rainfall } \\
\text { During the } \\
\text { Long Rain } \\
\text { Season }\end{array}$ & $\begin{array}{l}\text { Peak Month } \\
\text { of Rainfall } \\
\text { During the } \\
\text { Short Rain } \\
\text { Season }\end{array}$ & $\begin{array}{l}\text { Onset Month } \\
\text { of Rainfall } \\
\text { During the } \\
\text { Short Rain } \\
\text { Season }\end{array}$ & $\begin{array}{l}\text { Cessation } \\
\text { Month of } \\
\text { Rainfall During } \\
\text { the Short Rain } \\
\text { Season }\end{array}$ \\
\hline 1985 & April & April & July & November & November & December \\
\hline 1986 & April & April & July & December & December & January \\
\hline 1987 & May & April & July & November & October & December \\
\hline 1988 & May & March & June & October & October & January \\
\hline 1989 & April & April & June & October & October & January \\
\hline 1990 & April & March & June & October & October & December \\
\hline 1991 & March & March & June & November & November & December \\
\hline 1992 & April & April & June & October & October & November \\
\hline 1993 & May & April & July & November & October & December \\
\hline 1994 & May & March & July & November & November & December \\
\hline 1995 & March & March & July & October & October & December \\
\hline 1996 & May & March & September & November & November & December \\
\hline 1997 & April & April & June & November & October & December \\
\hline 1998 & May & April & July & November & November & December \\
\hline 1999 & March & March & June & December & November & January \\
\hline 2000 & April & April & September & November & October & December \\
\hline 2001 & April & March & September & October & October & December \\
\hline 2002 & April & March & June & December & October & January \\
\hline 2003 & May & March & June & October & October & December \\
\hline 2004 & April & March & June & December & October & January \\
\hline 2005 & May & March & July & October & October & December \\
\hline 2006 & May & March & June & November & October & January \\
\hline 2007 & May & April & June & October & October & December \\
\hline 2008 & March & March & June & October & October & December \\
\hline 2009 & May & April & June & December & October & January \\
\hline 2010 & March & March & June & October & October & December \\
\hline 2011 & May & March & June & November & October & December \\
\hline 2012 & April & April & June & October & October & January \\
\hline 2013 & April & March & August & December & November & January \\
\hline 2014 & May & March & June & October & October & January \\
\hline 2015 & April & April & June & November & October & January \\
\hline
\end{tabular}

**. Correlation is significant at the 0.01 level (2-tailed). 


\subsection{Temperature Trends}

\subsubsection{Annual Average Temperature Trend}

Temperature being the other key indicator of climate variability, this study also seeked to determine the temperature variations of the area for the last 30 years (1985 to 2015). The mean annual temperature in the area has generally been increasing since 1985 to 2015 . The lowest average temperature recorded in Bahati Sub-County was $17.7^{\circ} \mathrm{C}$ in 1989 , while the highest temperature recorded was $19.7^{\circ} \mathrm{C}$ in 2009 , (Fig. 6) and this coincides with the years 1987,2000 and 2009 when Kenya experienced the worst droughts. According to [9], seasonal temperature changes observed could alter the growing, planting and harvesting time for agricultural production.

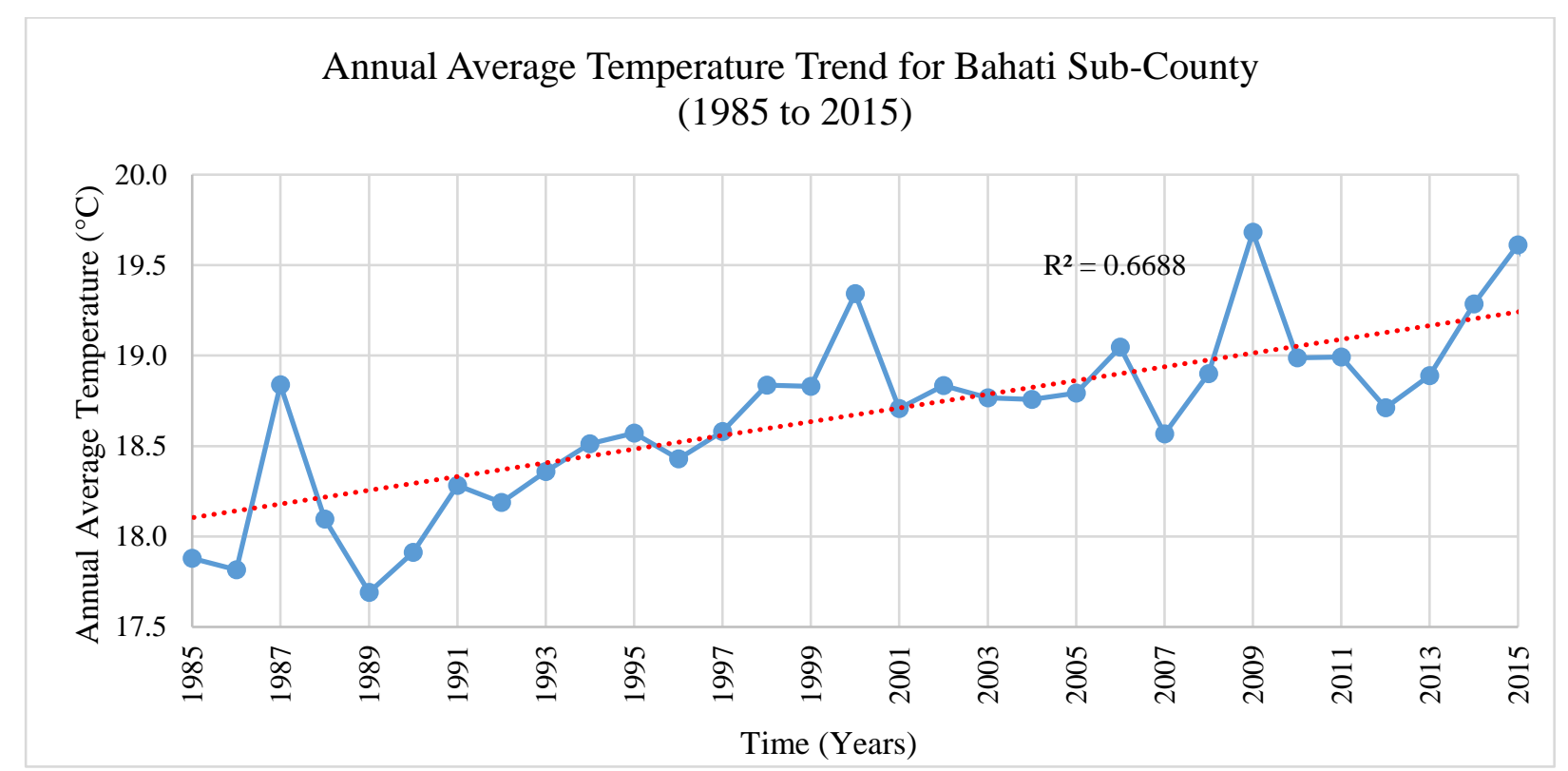

Figure 6: Annual Average Temperature Trend for Bahati Sub-County

\subsubsection{Annual Average Maximum Temperature Trend}

The maximum average temperature for the Bahati Sub-County (1985 to 2015) was $25.8^{\circ} \mathrm{C}$, while the highest maximum annual temperature was recorded in 1987 and 2009 at $27.0^{\circ} \mathrm{C}$ and the lowest in 1989 at $24.8^{\circ} \mathrm{C}$ as shown in Fig. 7. The Trend line equation shows that Bahati-Sub-County has been experiencing a slightly gradual increase of $0.008^{\circ} \mathrm{C}$ annually in the maximum temperature for the period 1985 to 2015 . 


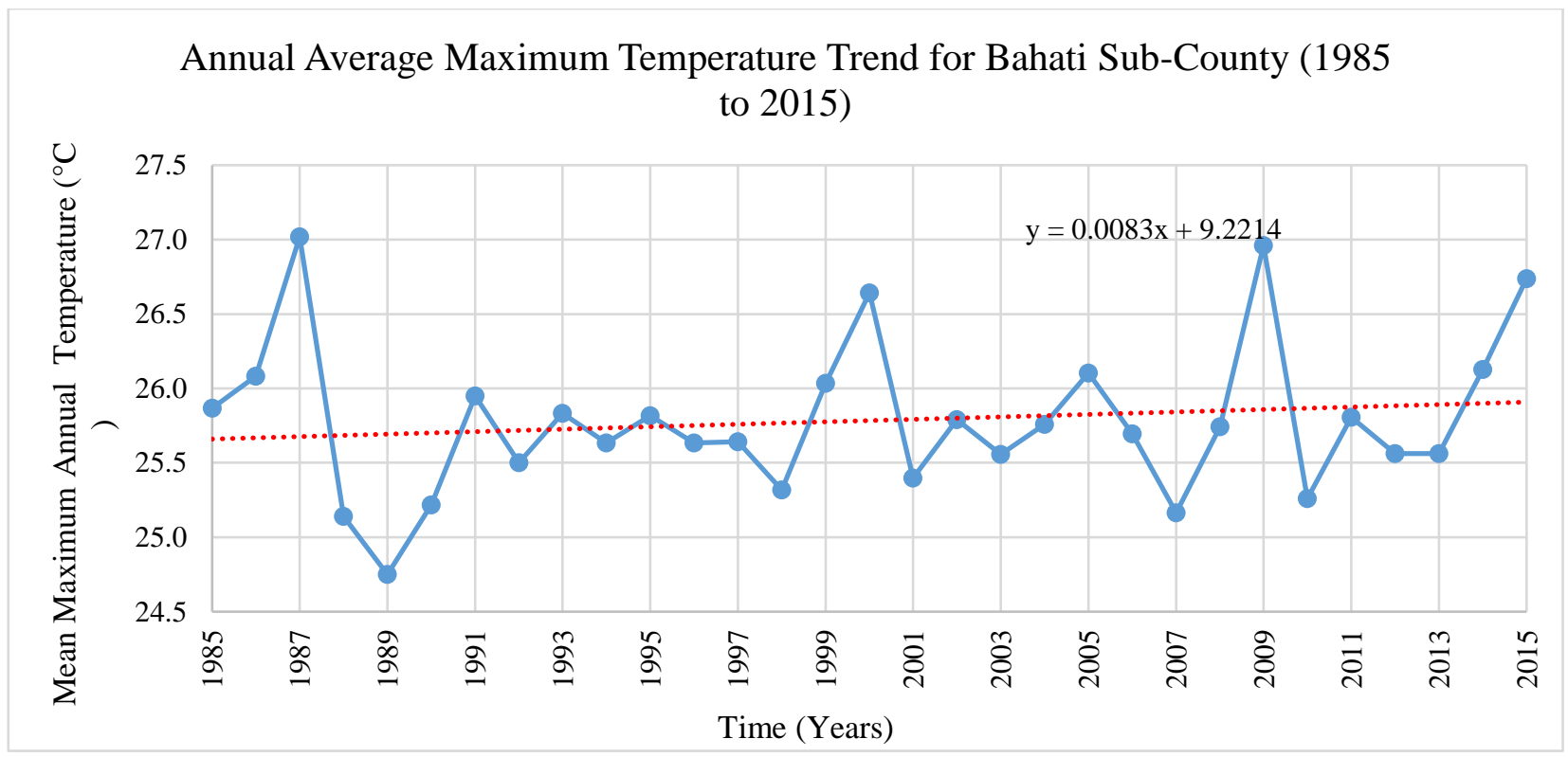

Figure 7: Annual Average Maximum Temperature for Bahati Sub-County

\subsubsection{Annual Average Minimum Temperature Trend}

The minimum average temperature for Bahati Sub-County for the period 1985 to 2015 was recorded at $11.6^{\circ} \mathrm{C}$. The lowest temperature recorded was in 1986 at $9.6^{\circ} \mathrm{C}$ and the highest minimum temperature recorded was in 2010 at $12.7^{\circ} \mathrm{C}$ as shown in Fig. 8. The trend line equation shows that there has been a gradual increase of $0.075^{\circ} \mathrm{C}$ in minimum temperature for Bahati Sub-County for the period 1985 to 2015.

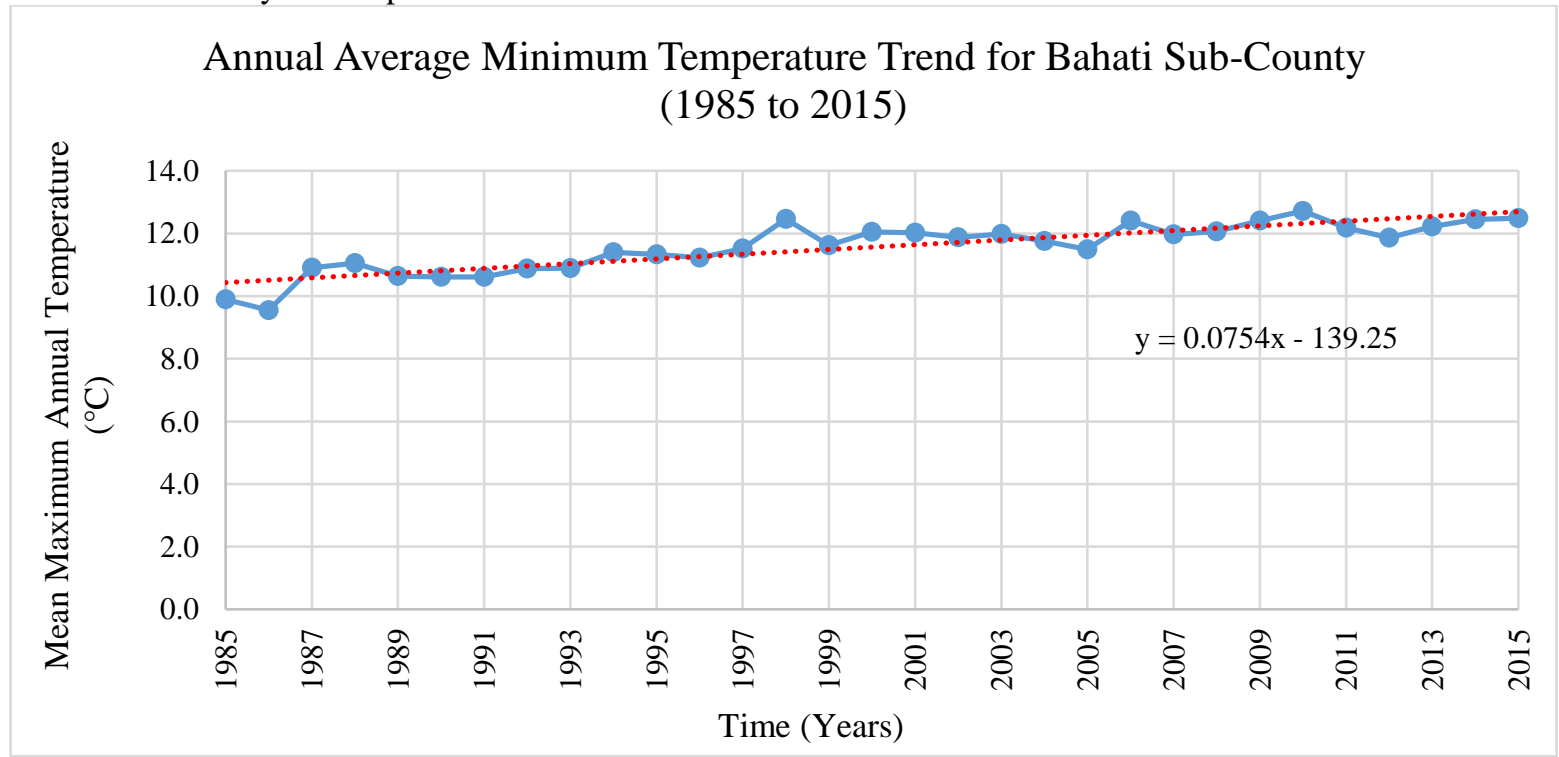

Figure 8: Annual Average Minimum Temperature for Bahati Sub-County

\subsection{Temperature Variability}

\subsubsection{Annual Average Temperature Variations}

Annual average temperature variability characteristics for Bahati Sub-County showing the anomalies for the period 1985 to 2015 was presented in a graph as shown in Fig. 9. Annual average temperature variability ranged from $17.7^{\circ} \mathrm{C}$ in 1989 to $19.7^{\circ} \mathrm{C}$ in 2009 (Fig. 6). The highest average temperature anomalies were recorded in the years $1986\left(-0.88^{\circ} \mathrm{C}\right), 1989(-$ $\left.1.0^{\circ} \mathrm{C}\right), 2009\left(+0.98^{\circ} \mathrm{C}\right)$, and $2015\left(+0.91^{\circ} \mathrm{C}\right)$ as shown in Fig. 9. 
Annual Average Temperature Variations from the Mean for Bahati SubCounty (1985 to 2015)

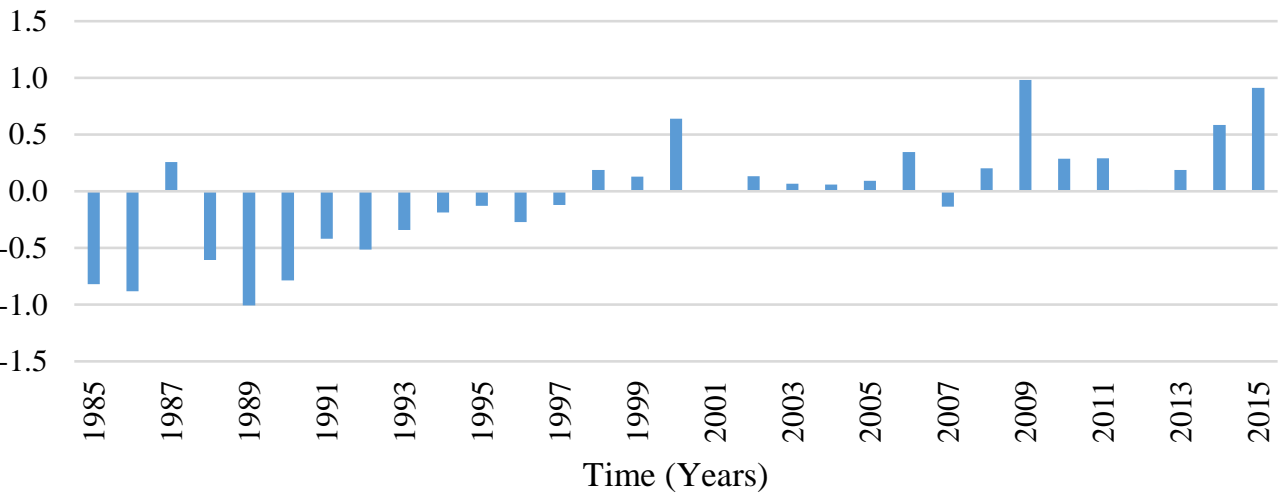

Figure 9: Annual Average Temperature Variations for Bahati Sub-County

\subsubsection{Annual Average (Maximum and Minimum) Temperature variations from the Mean.}

Maximum and minimum temperature variability for Bahati Sub-County for the period 1985 to 2015 was recorded as significant with maximum temperature variations peaks noted during the years $1987\left(+1.2^{\circ} \mathrm{C}\right), 1988\left(-0.7^{\circ} \mathrm{C}\right), 1989\left(-1.1^{\circ} \mathrm{C}\right)$, and $2009\left(+1.2^{\circ} \mathrm{C}\right)$ as shown in Fig. 10. During the minimum temperature variations, high temperature variations were recorded during the years $1985\left(-1.7^{\circ} \mathrm{C}\right), 1986\left(-2.1^{\circ} \mathrm{C}\right)$ and in $2010\left(+1.1^{\circ} \mathrm{C}\right)$.

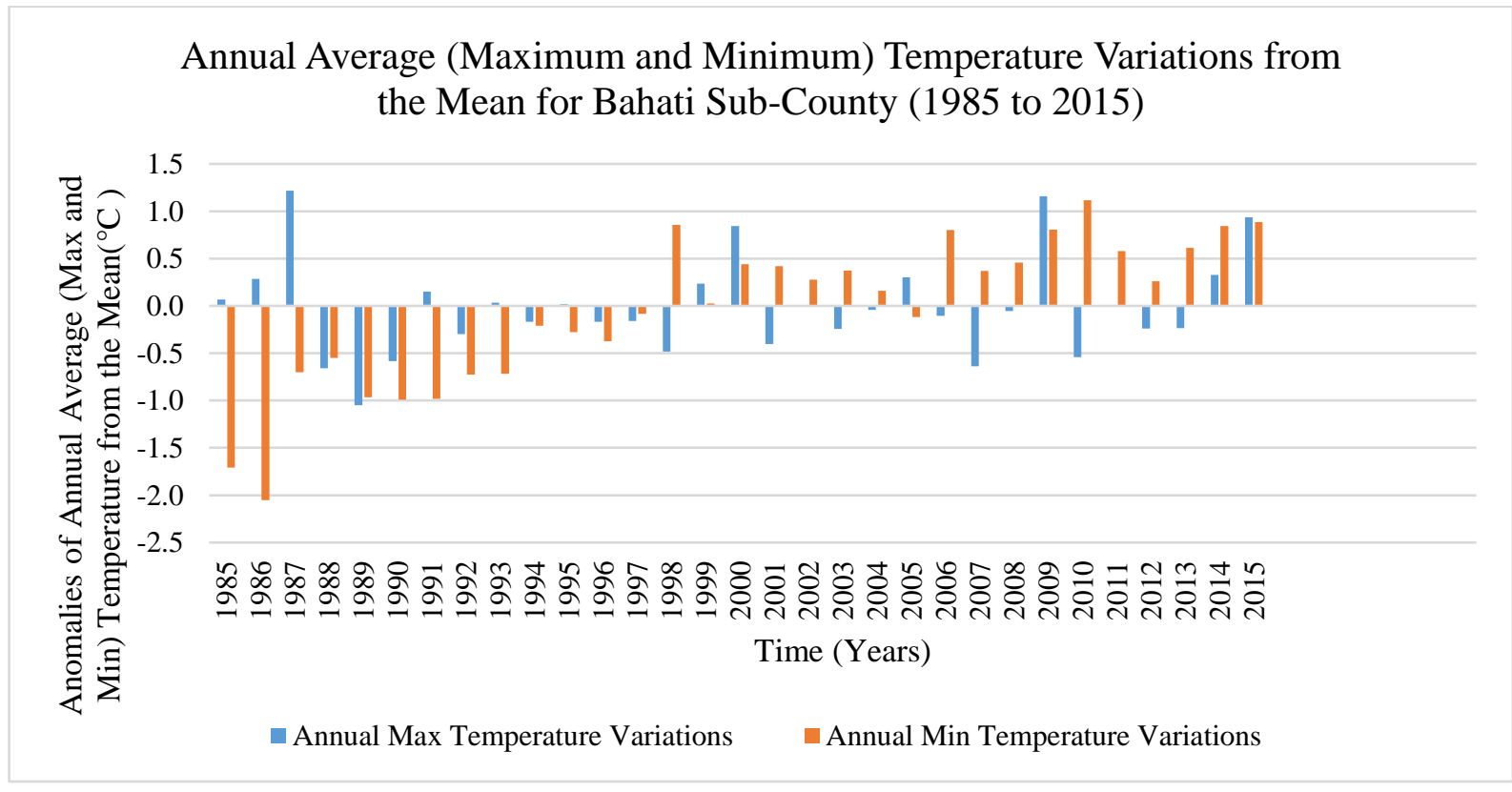

Figure 10: Annual Average (Max. and Min.) Temperature Variations for Bahati Sub-County

Table 2: Summary of Recorded Rainfall and Temperature Data for Bahati Sub-County (1985 to 2015)

\begin{tabular}{|l|l|l|}
\hline Annual & Rainfall $(\mathbf{m m})$ & Temperature $\left({ }^{\circ} \mathbf{C}\right)$ \\
\hline Maximum & $1436.2 \mathrm{~mm}$ & $27.0^{\circ} \mathrm{C}$ \\
\hline Minimum & $580.9 \mathrm{~mm}$ & $9.6^{\circ} \mathrm{C}$ \\
\hline Mean & $960.4 \mathrm{~mm}$ & $18.7^{\circ} \mathrm{C}$ \\
\hline
\end{tabular}

Source: Kenya Meteorological Department (1985 to 2015) 


\subsection{Correlation Analysis}

\subsubsection{Correlations of Annual Rainfall, Maximum Annual Temperature and Minimum Temperature}

The annual rainfall trend, maximum temperature trend and minimum temperature trend as shown on Table 4 were correlated to determine the significance of their relationship. When Pearson's $r$ is close to 1, this means that there is a strong relationship between the two variables and that changes in one variable are strongly correlated with changes in the second variable. When Pearson's $r$ is close to 0 this means that there is a weak relationship between the two variables and that the changes in one variable are not correlated with changes in the second variable. From the findings on Table 4, Pearson's $(r=-0.716, p=0.000)$ is close to -1 showing that there is a significant strong and negative linear relationship between annual rainfall amount and maximum temperature. Pearson's $\mathrm{r}(\mathrm{r}=0.151, \mathrm{p}=0.418)$ recorded between annual rainfall and minimum temperature indicated an insignificant, weak and negative relationship between the two variables. A positive Pearson's $r$ indicates that as one variable increases, the second variable also increase in value or vice versa.

Table 3: Annual Rainfall, Maximum Annual Temperature and Minimum Temperature (1985 to 2015)

\begin{tabular}{|l|l|l|l|}
\hline Years & $\begin{array}{l}\text { Annual Rainfall Amount } \\
(\mathbf{m m})\end{array}$ & $\begin{array}{l}\text { Maximum Annual } \\
\text { Temperature Amount }\left({ }^{\circ} \mathbf{C}\right)\end{array}$ & $\begin{array}{l}\text { Minimum Annual } \\
\text { Temperature Amount } \\
\left({ }^{\mathbf{C}}\right)\end{array}$ \\
\hline 1985 & 987 & 25.9 & 9.9 \\
\hline 1986 & 934.2 & 26.1 & 9.6 \\
\hline 1987 & 697.2 & 27.0 & 10.9 \\
\hline 1988 & 1243.6 & 25.1 & 11.1 \\
\hline 1989 & 1145.4 & 24.8 & 10.6 \\
\hline 1990 & 978.6 & 25.2 & 10.6 \\
\hline 1991 & 768.4 & 26.0 & 10.6 \\
\hline 1992 & 979.8 & 25.5 & 10.9 \\
\hline 1993 & 703.9 & 25.8 & 10.9 \\
\hline 1994 & 790.4 & 25.6 & 11.4 \\
\hline 1995 & 917.8 & 25.8 & 11.3 \\
\hline 1996 & 933.1 & 25.6 & 11.2 \\
\hline 1997 & 1094.2 & 25.6 & 11.5 \\
\hline 1998 & 988.4 & 25.3 & 12.5 \\
\hline 1999 & 656.8 & 26.0 & 11.6 \\
\hline 2000 & 610 & 26.6 & 12.0 \\
\hline 2001 & 1129.8 & 25.4 & 12.0 \\
\hline 2002 & 1083.7 & 25.8 & 11.8 \\
\hline 2003 & 1137.6 & & 12.0 \\
\hline 2004 & 891.7 & 25.6 & \\
\hline & & 25.8 & \\
\hline
\end{tabular}




\begin{tabular}{|l|l|l|l|}
\hline 2005 & 884.5 & 26.1 & 11.5 \\
\hline 2006 & 971.5 & 25.7 & 12.4 \\
\hline 2007 & 1217.3 & 25.2 & 12.0 \\
\hline 2008 & 825.8 & 25.7 & 12.1 \\
\hline 2009 & 705.33 & 27.0 & 12.4 \\
\hline 2010 & 1436.2 & 25.3 & 12.7 \\
\hline 2011 & 1109.9 & 25.8 & 12.2 \\
\hline 2012 & 1134 & 25.6 & 11.9 \\
\hline 2013 & 1184.8 & 25.6 & 12.2 \\
\hline 2014 & 814.8 & 26.1 & 12.4 \\
\hline 2015 & 816.7 & 26.7 & 12.5 \\
\hline
\end{tabular}

Table 4: Summary of Correlations between Annual Rainfall, Maximum Annual Temperature and Minimum Temperature for Bahati Sub-County

\begin{tabular}{|c|c|c|c|c|}
\hline & & $\begin{array}{c}\text { Rainfall } \\
(\mathrm{mm})\end{array}$ & $\begin{array}{c}\text { Maximum } \\
\text { Temperature }\left({ }^{\circ} \mathbf{C}\right)\end{array}$ & $\begin{array}{c}\text { Minimum } \\
\text { Temperature }\left({ }^{\circ} \mathbf{C}\right)\end{array}$ \\
\hline \multirow[t]{3}{*}{ Rainfall (mm) } & Pearson Correlation & 1 & $-.716^{* *}$ & .151 \\
\hline & Sig. (2-tailed) & & .000 & .418 \\
\hline & $\mathrm{N}$ & 31 & 31 & 31 \\
\hline \multirow{3}{*}{$\begin{array}{l}\text { Maximum } \\
\text { Temperature }\left({ }^{\circ} \mathbf{C}\right)\end{array}$} & Pearson Correlation & $-.716^{* *}$ & 1 & .081 \\
\hline & Sig. (2-tailed) & .000 & & .663 \\
\hline & $\mathrm{N}$ & 31 & 31 & 31 \\
\hline \multirow{3}{*}{$\begin{array}{l}\text { Minimum } \\
\text { Temperature }\left({ }^{\circ} \mathbf{C}\right)\end{array}$} & Pearson Correlation & .151 & .081 & 1 \\
\hline & Sig. (2-tailed) & .418 & .663 & \\
\hline & $\mathrm{N}$ & 31 & 31 & 31 \\
\hline
\end{tabular}

**. Correlation is significant at the 0.01 level (2-tailed).

\subsection{Climate Variability}

\section{DISCUSSION}

The study found out that the annual rainfall had reduced between 1985 and 2015 in Bahati Sub-County.

High amounts of rainfall were noticed in the years $1988(1244 \mathrm{~mm}), 1992(980 \mathrm{~mm}), 1997$ (1094mm), 2001 (1130mm), 2002 (1084mm), $2003(1138 \mathrm{~mm}), 2007(1217 \mathrm{~mm}), 2010(1436 \mathrm{~mm})$ and $2013(1185 \mathrm{~mm})$, while low amounts of rainfall are noticed in the years $1987(697 \mathrm{~mm}), 1993(704 \mathrm{~mm}), 2000(610 \mathrm{~mm})$ and $2009(705 \mathrm{~mm})$. Seasonal rainfall variability was 
found to be significant in the long and short rain season trend and ranged from $-253.17 \mathrm{~mm}$ (2000) to $+263.53 \mathrm{~mm}$ (2010) and from $-111.08 \mathrm{~mm}(1985)$ to $+247.31 \mathrm{~mm}$ (1997) respectively. The mean annual temperature in the area has generally been increasing since 1985 to 2015 . The lowest average temperature recorded in Bahati Sub-County was $17.7^{\circ} \mathrm{C}$ in 1989 , while the highest temperature recorded was $19.7^{\circ} \mathrm{C}$ in 2009 , (Fig. 6). The trend line equation showed that Bahati-SubCounty has been experiencing a slightly gradual increase of $0.008^{\circ} \mathrm{C}$ annually in the maximum temperature for the period 1985 to 2015 . While the highest maximum annual temperature was recorded in 1987 and 2009 at $27.0^{\circ} \mathrm{C}$ and the lowest in 1989 at $24.8^{\circ} \mathrm{C}$ as shown in Fig. 7. The trend line equation showed that there has been a gradual increase of $0.075^{\circ} \mathrm{C}$ in minimum temperature for Bahati Sub-County for the period 1985 to 2015 . The lowest temperature recorded was in 1986 at $9.6^{\circ} \mathrm{C}$ and the highest minimum temperature recorded was in 2010 at $12.7^{\circ} \mathrm{C}$ as shown in Fig. 8 .

\section{CONCLUSIONS}

The main objective of the study was to analyze the climate variability trends in Bahati Sub-County, Kenya for the period 1985 to 2015. The study found out that the annual rainfall amounts had decreased over the years, while maximum and minimum temperatures over the years have gradually been increasing. The correlation analysis revealed that there is a significant, negative and strong relationship between annual rainfall trend and maximum temperature $(r=-0.716, p=0.000)$. However, the study findings also revealed that the relationship between annual rainfall and minimum temperature had an insignificant, weak and negative relationship $(r=0.151, p=0.418)$. Furthermore, the study findings revealed that there has been a shift in the onset and cessation of rainfall. The onset month for long rain season has been alternating from March to April while the cessation month has been alternating from June to August. The onset month for the short rainy season has varied alternating between October to December, while the Cessation month has also varied alternating between November to January.

\section{ACKNOWLEDGEMENTS}

I would like to acknowledge the assistance and support accorded to me by the Kenya Meteorological Department, Department of Geography in Kenyatta University and Department of Earth Sciences in Uppsala Universitet.

\section{REFERENCES}

[1] Adeniyi M., Ogunsola O., Nymphas E, and Oladiran O. (2009). Food Security Measures During Uncertain Climatic Conditions in Nigeria. University of Ibadan, Ibadan, Nigeria. African Journal of Food Agriculture Nutrition and Development, 9:652-677.

[2] Bals, C., Harmeling, S. and Windfuhr, M., (2008). Climate change, food security and the right to adequate food. Stuttgart, Germany: Diakonie Katastrophenhilfe, Brot fuer die Welt and German Watch.

[3] Government of Kenya, (2013). National Climate Change Action Plan 2013 -2017. Government printers, Nairobi, Kenya.

[4] Hansen, J., Sato, M., Ruedy, R., Lo, K., Lea, D.W. and Medina-Elizade, M. (2006). Global temperature change. Proceedings of the National Academy of Sciences of the United States of America, 103(39).

[5] IITA. (2004). Annual report for Ibadan, Nigeria. International Institute for Tropical Agriculture.

[6] IPCC. (2007). Climate Change 2007: Impacts, adaptation and vulnerability: Contribution of Working Group II to the fourth assessment report of the Intergovernmental Panel on Climate Change. Cambridge University Press, Cambridge, UK.

[7] KNBS. (2009). Kenya Population and Housing Census. Population Distribution by Age, Sex and Administrative Units, IC. Kenya National Bureau of Statistics, Nairobi: Kenya.

[8] Makokha, G. L. and Shisanya, C.A. (2010). Trends in Mean Annual Minimum and Maximum Near Surface Temperature in Nairobi City, Kenya. Advances in Meteorology, 2010: 6.

[9] Mark, W., Mandy, E., Gary, Y., Lan, B., Saleemul, H., and Rowena, V. (2008). Climate Change and Agriculture. Threats and Opportunities. Federal Ministry for Economic Cooperation and Development, Germany.

[10] Omoyo, N.N., Wakhungu, J. and Oteng'i, S. (2015). Effects of climate variability on maize yield in the arid and semi-arid lands of lower eastern Kenya. Agriculture and Food Security 4:8.

[11] Shisanya, C.A., Recha, C. and Anyamba, A. (2011). Rainfall Variability and Its Impact on Normalized Difference Vegetation Index in Arid and Semi-Arid Lands of Kenya. International Journal of Geosciences, 2, 36-47 